\title{
EWSR1/ETV1 Fusion Gene
}

National Cancer Institute

\section{Source}

National Cancer Institute. EWSR1/ETV1 Fusion Gene. NCI Thesaurus. Code C99259.

A fusion gene that results from a chromosomal translocation $\mathrm{t}(7 ; 22)(\mathrm{p} 22 ; \mathrm{q} 12)$ which fuses exon 7 of the EWSR1 gene to either exon 10 or 11 of the ETV1 gene. This rearrangement is associated with Ewing sarcoma. 